\section{Organisaation kolmiyhteys}

Onnismaa, Jussi (2021). Organisaation aika, muisti ja etiikka. Basam Books. 220 sivua.

JATKUVASSA MUUTOKSESSA elävissä organisaatioissa voidaan tunnistaa varsin monenlaista käsitteistöä. Tietokirjailija, dosentti Jussi Onnismaa luo kirjassaan varsin mielenkiintoisen ja monikerroksisen kudelman siitä, miten erilaisiin merkityksiin tututkin peruskäsitteet saattavat lopulta asettua, kun ne viedään käytäntöön organisaatioissa.

'Organisaatiolla' kirjoittaja tarkoittaa ihmisten yhteenliittymää jonkin tietyn toiminnan tai tavoitteen saavuttamiseksi. Tavoitteisiin pyritään viestinnän avulla säätelemällä käytössä olevia resursseja sekä jakamalla työtä ja valtaa. Kun kyseessä ovat eri toimijat, on helppo arvata, että jakoperusteet ja merkityksetkin eroavat lopulta paljon.

Esimerkistä käy kollektiivinen muisti. Sosiaalisella jakamisella ja dialogia ylläpitävillä kertomuksilla on menneisyydestä luotu organisaatiossa yhteisesti hyväksytty tulkinta, josta muotoutuu muisti. Sillä ei siten voi olla yhtä ainoaa totuutta, vaan tulkintaa uusinnetaan kertomalla yhä uudelleen samaa kertomusta tulokkaille: saman menneisyyden kokeneet voivat muistaa asian hyvinkin eri tavoin. Kulttuurinen tausta vaikuttaa lisäksi siihen, kenestä tulee tarinan hyviksiä, pahiksia tai uhreja. Se mitä ei syystä tai toisesta muisteta, voi olla tietoisesti unohdettua. Muistamattomuus ei tarkoita, ett- eikö asiaa olisi tapahtunut.

Ja muun muassa näistä aineksista ja tulkinnoista rakentuvat organisaatiokulttuurit, joiden perusteorioita Organisaation aika, muisti ja etiikka käy läpi monitieteisesti, elävän elämän esimerkeillä höystettynä. Monipuolinen käsittely saa lukijassa aikaan näkökulmien laajentumisen: organisaatiokulttuurin kudelma on huomattavasti monipuolisempi kuin ensipohtimalla voisi kuvitella.

Mielenkiintoinen käsite on myös 'aika'. Menneisyyttä, nykyisyyttä ja tulevaa voidaan tarkastella hyvinkin erilaisista näkökulmista. Ajan kestolla voi eri organisaatiossa olla erilaisia merkityksiä. Onnismaa jakaa ajan seuraavasti: 1) organisaatioiden hidas aika ja pitkä kesto, 2) soljuva aika eli prosessiaika, 3) teknorytmiaika eli projektiaika ja 4) takaperoinen "olisi pitänyt" -aika.

Vaikka elämme samalla aikavyöhykkeellä, ajan kestossa ja rytmissä on eroja. Aika on lisäksi vallankäytön väline, jolla kontrolloidaan tekemistä - Onnismaa puhuukin ajan kolonisoinnista ja aikakurista. Aikaan ja tilanteisiin voi vaikuttaa monin tavoin. Aika voi olla erilaista isossa ja pienessä organisaatiossa, ja luonnollisesti organisaatiokulttuuri vaikuttaa aikakäsitykseen.

Projektityöläisen aika voi olla peräkkäistä ta jaksottaista. Se voi
JUSSI ONNISMAA

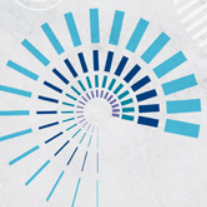

ORGANISAATION AIKA, MUISTI JA ETIIKKA

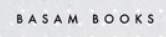

olla uutta odottelevaa aikaa, jossa menneisyys, nykyisyys ja tulevaisuus asettuvat limittäin. Ajan suhde tilaan on kiehtova: tilanne voi viedä aikaa, kun taas toisaalla aika määrittää tilannetta.

'Aika' on ristiriitainen käsite, ovathan monet tehtävät samanaikaisia. Erityisen elävästi tämä näkyy tietotyössä, jossa ihannoidaan nopeaa reagointia. Se edellyttää multitaskausta, jota on pidetty ihanteena mutta joka lopulta saattaa olla varsin tehotonta toimintaa. Katkokset ovat moniaikaisessa työssä usein itseaiheutettuja. Erilaisten aikojen synkronointi ja itselle sovittaminen voi osoittautua vaikeaksi.

\section{DIALOGISUUS SYVENTÄÄ VUOROVAIKUTUSTA}

Usein pohditaan vuorovaikutuksen ja dialogisuuden eroja. Dialogisuus on vuorovaikutuksen se osa, jonka avulla päästään syvemmälle. Yhteistoiminnallisuus voi olla luomassa yhtä lailla 
järjestystä tai kaaosta. Onnistunut dialogisuus edellyttää luottamusta ja yhä lisääntyvä verkostomainen työskentely vastavuoroisuutta. Silti voidaan pohtia, kumpi verkostoissa lopulta oppii: organisaatio vai yksilö, ja onko oppiminen perustyön kannalta välttämättä edes olennaista.

Dialogiset käytännöt vaativat usein pitkäjänteistä työtä ja vuorovaikutusta. Muutostenkin tulisi lähteä liikkeelle ihmisestä itsestään: oman toiminnan kehittäminen on aina mahdollista, muiden muuttaminen välttämättä ei. Dialogin avulla voidaan nähdä toisin ja kohdata erilaisuutta uusin ta- voin, jos mukana ovat olennaiset asiat eli kuuntelu, arvostus ja palaute: "Kuinka puhun niin, että toisessa syntyy halua kuunnella ja kuinka kuuntelen niin, että toisessa syntyy halu puhua."

Onnismaa tuo myös esille ristiriitaisuuksia, kuten työelämän, jossa toimitaan tiimeissä, mutta palkitaan yksilöitä. Nopeat muutokset voidaan kokea historiattomuutena, muistamattomuutena ja alusta aloittamisena, ja silti jatkuva muutos on välttämättömyys.

Organisaation aika, muisti ja etiikka vaatii lukijaa pysähtymään ja pohtimaan. Esimerkiksi eettisissä ja moraalisissa kysymyksissä ei voida puhua mustavalkoisesti vain hyvästä ja huonosta. Totuuksia voi olla useita, ja konteksti voi vaikuttaa valintoihin. Se myös haastaa monipuolisuudellaan: Onnismaa puhuu rinnakkain niin vuorovaikutuksesta ja johtajuudesta kuin eettisistä merkityksistä. Ensilukemalta jäin kaipaamaan tarkempaa rajausta, mutta toisen lukukerran jälkeen ymmärsin rajauksen kokonaisuuden kannalta: viime kädessä kaikki vaikuttaa kaikkeen.

HELI ANTILA

KM, YTM, projektipäällikkö Joustavat koulutusmallit yhdessä yrityselämän kanssa -hanke Keuruun kaupunki

\section{KUTSU Aikuissassatuksen Tutkimusseuran

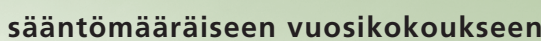

Aika: 10.2.2022 klo 17.30-18.30

Paikka: Tampereen yliopisto, Päätalo A2a, Kalevantie 4, 33100 Tampere

Tervetuloa Aikuiskasvatuksen Tutkimusseuran sääntömääräiseen vuosikokoukseen, joka järjestetään Tampereen yliopiston Päätalossa tilassa A2a torstaina 10. helmikuuta 2022 kello 17.30-18.30.
Aikuiskasvatus-tiedelehden vuoden tiedeartikkeli ja opiskelijan tunnustuspalkinto jaetaan Aikuiskasvatuksen tutkimuspäivien iltajuhlassa 10. helmikuuta. Tutkimuspäivät järjestetään 10.-11. helmikuuta Tampereen yliopistolla.

Tutustu: https://events.tuni.fi/aitu2022

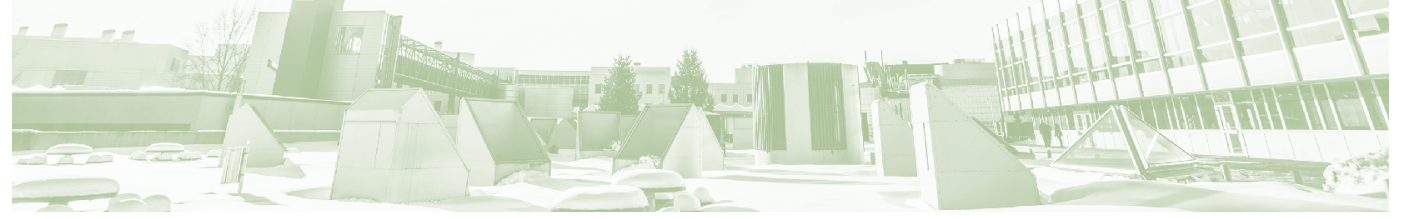

